\title{
Coping With Teacher Demotivation Toward Directed Motivational Currents
}

\author{
Toshiko Sugino \\ Kogakuin University, Tokyo, Japan
}

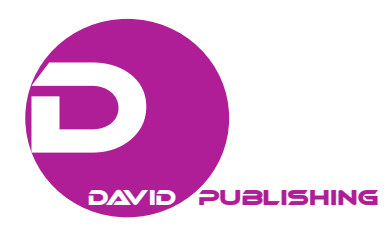

Mami Ueda

Chiba Prefectural University of Health Sciences, Chiba, Japan

\begin{abstract}
In the field of Second Language Acquisition (SLA), motivation has played a crucial role for language learning and teaching. Just as motivation is important in SLA, demotivation constitutes an important factor for both students and teachers. In our previous study, investigating 97 teachers for demotivational factors, the teachers felt demotivated to see students' lack of interest and bad attitudes, as well as dissatisfaction with curriculum, teaching material and poor facilities. We concluded further investigation was necessary as to how teachers regain motivation and hopefully toward directed motivational current (DMC), which not only provides a direction for action, but it also energizes action (Dörnyei et al, 2016). In our present study, compared to our previous study which was analyzed quantitatively, we have collected qualitative data from some 34 college teachers investigating when they felt demotivated, what they did to cope with it, and how they regained their motivation. Data was collected, analyzed qualitatively, and factors which may lead to DMC was extracted. It is hoped that this study will be beneficial for facilitating better SLA learning and teaching, and also for teacher training.
\end{abstract}

Keywords: teacher demotivation, student demotivation, language education, directed motivatinal currents

\section{Introduction}

Do you feel a teacher's job is rewarding? Are you satisfied with your teaching job? Do you feel you are cut for this occupation as a teacher? Even though you yourself have chosen this occupation, these questions may be difficult to answer.

University English language education in Japan is often characterized as "a permanent sense of crisis" because students are finally free from "exam hell” upon graduating from high school (Ushioda, 2013), and enjoy "leisure land" as Clark (2010) commented cynically on university education, and was once described as "motivational wasteland" (Berwick \& Ross, 1989). At the same time, catching up with greater internationalization among universities in advanced countries, the Japanese government came up with the idea of

Toshiko Sugino was a former Full Professor, presently teaching at various institutions. Received her EdD at Temple University. She serves as TLT Japanese-language Editor. Has published extensively on SLA and language policies.

Emika Abe is a Lecturer of English at Daito Bunka University. She also teaches Japanese to International students. She has done extensive research on learner autonomy and motivation with self-regulatory strategies.

Mami Ueda was a Full Professor now lecturing at Chiba Prefectural University of Health Sciences. She has published extensively on learner autonomy, student motivation, and motivational strategies. 
implementing educational reform. Over the last 20 years, universities have dealt with self-evaluation, faculty development, implementation of more student-centered with syllabi with content and task-based instructions.

With the new type of instructions, when we see that students have learned something from what we teach and if they find joy in studying, we feel motivated. Teachers also feel motivated when they see students' motivation and progress, and when teachers are appreciated for that. However, the same thing can be said in a different direction, meaning when teachers see students who are not interested in studying or unwilling to learn, we feel demotivated.

Demotivation is a crucial factor for SLA research. According to Dörnyei (2000), demotivation in SLA and learning is the flip side of motivation, and concerns specific external forces that negatively affect learners' willingness to study the language and also affect teachers' willingness to teach.

As mentioned by Ushioda (2013), Japan leads the field in the demotivational area of research inquiry as demotivation is obviously viewed as a significant phenomenon in English language education in Japan (p. 6). In the past ten years, we can find several key studies such as Arai (2004), Tsuchiya (2006), and Agawa et al. (2011). These studies researched demotivating factors of students and identified some; such as a sense of English uselessness, a sense of incompetence, an inconsistent way of studying, a sense of discouragement, and a lack of acceptance (Tsuchiya, 2006).

However, despite the importance of demotivational studies to understand L2 learning in more depth, only a limited number of studies are available on teacher demotivation. In our previous research (Sugino, 2010), a survey was conducted with some 97 teachers investigating teacher demotivation in Japan. The survey revealed that student attitudes, such as the items "when students use cell-phones, and when students sleep in class," demotivate the teachers the most.

Dornyei et al. (2016) claimed a new framework of motivational research called Directed Motivational Currents (DMC). A DMC is an important phenomenon because it contains a considerable amount of highly concentrated fuel for action, and it is an intense motivational drive-or-surge, which is capable of stimulating and supporting long-term behavior. That is why a DMC is not just a pathway toward a goal: an interesting theoretical aspect is that it not only provides a direction for action, but it also energizes action. It distinguishes a DMC from most other motivational constructs described in the literature.

In this paper, compared to our previous study which was quantitative, we collected qualitative data from some 34 college teachers investigating when they felt demotivated, what they did to cope with it, and how they regained their motivation. Data were collected, and analyzed qualitatively, and factors which may lead to DMC were extracted. It is hoped that this study will be beneficial for facilitating better SLA learning and teaching, and also for teacher training.

\section{Demotivational Research}

It is widely recognized that motivation is extremely important and a key factor for successful second language (L2) learning, though not everyone agrees on what motivation actually consists of (Oxford \& Shearin, 1994). At the same time, as mentioned earlier, demotivation is a crucial factor for SLA research and teaching as it concerns specific internal and external forces that negatively affect learners' willingness to study and affects teachers’ willingness to teach (Dörnyei, 2000). 


\section{Students’ Demotivational Factors}

As mentioned earlier, Ushioda (2013) pointed out that Japan leads the field in demotivational research areas as demotivation is obviously viewed as a significant phenomenon in English language education in Japan (p. 6). In the past ten years, we can find several key studies such as Arai (2004), Tsuchiya (2006), and Falout and Maruyama (2004). Arai (2004) surveyed 33 high proficiency university English majors, and found that the demotivating reasons for them include teachers' attitudes toward students, teachers' personalities, teaching methods, and the teacher's language proficiency as well as simple and boring lessons with uninteresting teaching materials. In Tsuchiya's study (2006), she found six demotivating factors: a sense of English uselessness, a sense of incompetence, little admiration, an inconsistent way of studying, a sense of discouragement, and a lack of acceptance. Collecting anonymous responses of 164 Japanese college students, Falout and Maruyama (2004) found measurable differences in learner motivation between low- and high-proficiency students. The factors negatively affecting low-proficient students were self-confidence, attitudes toward L2 itself, courses, and teachers, but both sets of students attributed their motivation to disappointment in performance, course contents and pace, and the teacher (Falout \& Maruyama, 2004). Overall, they found that the low-proficiency students more often internalized negative experiences in secondary school English classes.

Upon attaining the goal of university entrance after going through "examination hell", many university students lose interest and the relevance for learning English, as mentioned earlier. The combination of negative variables indicates that many university Science and Engineering (S\&E) students in Japan are more likely than non-S\&E students to have negative L2 learning experiences and a corresponding lack of L2 motivation (Apple, Da Silva, \& Fellner, 2013, p. 56 ). They gave a questionnaire to 654 S\&E students, investigating the factors that are most influential in learning to possible L2 selves, and their study revealed that the students in this study showed a general interest in using English communicatively, but a below-average perception of their own speaking ability, less-than-positive perceptions of classroom dynamics and relatively high anxiety towards English use in the classroom proved hindrances to their high hopes for themselves as English-speaking professionals (Apple, Da Silva, \& Fellner, 2013, p. 68).

\section{Teacher Demotivational Studies}

Regarding teacher demotivation, however, there is very limited literature available, especially in the Japanese context, even though teacher motivation is an important factor for students' successful language learning (Kozloski, 2002). Kozloski found that the majority of those surveyed in his study did appear to have a high level of intrinsic motivation such as self-efficacy, adequate and supportive goals with professionalism, and though extrinsic rewards such as "pay" or positive teacher evaluations were supportive, intrinsic motivation was more accountable for teacher motivation (2002).

Yan (2009) introduced a set of suggestions by Williams and Burden (1997) regarding how to reduce student de-motivation, including "recognize the complexity of motivation," "be aware of both initiating and sustaining motivation," "discuss with the learners why they are carrying out activities," and "involve learners in making decisions related to learning the language."

Connie (2000) investigated the relationship between teacher motivation and demotivation in the Mexican context in a descriptive study and suggested that factors such as better performance among students, 
well-motivated students, successful activities, support and respect by administrators and flexible curriculums motivated the teachers, and factors such as lack of enthusiasm in teaching, low salary, lack of teaching materials, a heavy workload and an inflexible curriculum demotivated teachers.

In a qualitative study by Aydin (2012), using one Turkish female as a case-study and collecting data from three sources-MSN chats, face-to-face conversations, and a diary maintained by the participant-it was found that there are six main factors that cause demotivation during the EFL teaching process, including lack of knowledge of teaching methodology, lack of supportive material for classroom use, invalid central examinations and difficult working conditions, financial issues and heavy workloads.

In a study by Kiziltepe (2008), conducted with three hundred teachers aged between 33 and 65, it was stated that demotivating factors can be categorized into five headings: students, economics, structural and physical characteristics, research, and working conditions. Overall, the results showed that students are the main source of motivation and demotivation for university teachers in Turkey.

Kim T. Y. and Kim Y. K. (2015) conducted a survey to investigate initial career motives and demotivating factors for Korean teachers of English. Of 94 in-service EFL teachers, elementary school teachers accounted for $54 \%$ and $46 \%$ secondary school. Most salient demotivation factor was obstacles to communicative language teaching (difficulties teachers have in communicative ways), inadequate administrative support (lacking school and colleagues' support and heavy workloads), and lack of social recognition (their ability in EFL teaching is not appreciated). Besides, some teachers found it frustrating to teach students with a large gap in proficiency or students with low motivation.

Finally, in our previous research, a survey was conducted with some 97 teachers investigating teacher demotivation in Japan. Of the 97 participants 52 (53.6\%) taught at the Defense Academy of Japan, and 45 (46.4\%) at other private and national universities in Japan. The survey revealed that the first factor related to student attitudes with the items "when students use cell-phones," "When students sleep in class," "when the students are not interested in studying," and "when students take a rebellious attitude," demotivate the teachers the most. The mean numbers were the largest for "no consistency in curriculum with clear goals," and "low teacher evaluation from students”, and as for the teaching environment, "long meeting hours" and "a lot of paperwork demotivated teachers". Investigating whether there was a significant difference between 28 part-time and 69 full-time teachers, as for "no bonus", the means were about the same $(M=2.82)$. The biggest mean difference came from "a lot of paper work", for part-time teachers $(M=2.86)$ and full-time teachers $(M=3.85)$. Lacking research time came in next.

In our previous research, however, attention was paid more to data that were analyzed quantitatively but not qualitatively. We concluded therefore that further investigation was necessary as to how teachers regain motivation and hopefully toward directed motivational current (DMC), which not only provides a direction for action, but also energizes action (Dörnyei et al., 2016).

\section{Directed Motivational Currents}

In Dörnyei, Henry, and Muir (2016), Directed Motivational Currents (DMCs) is described as follows:

"We have seen, both in our own lives and in those of others around us, that there are specific periods when we seem to find ourselves in a particularly intensive state of focused productivity which allows us to achieve a 
great deal, often much more than we would have believed possible at the outset. It is as if every piece of a jigsaw falls magically into place and we 'get into the zone' (Preface ix)”.

Dörnyei et al. offer as follows as DMC’s key points (p. 18):

- A DMC is an intense motivational drive-or-surge, which is capable of stimulating and supporting long-term behavior (such as the learning of an L2).

- A DMC is similar to the flow experience in some aspects (most notably the learners' absorption in the action) but different in others (most specifically their timescales, the differing sources of positive emotionality, and the structures underpinning them).

- The tasks which make up a DMC pathway will inevitably consist of activities which both would and would not be perceived as enjoyable in their own right; however, regardless of their inherent "enjoyability" in normal circumstances, all tasks along a DMC pathway are perceived as enjoyable because they transport an individual toward a highly valued end-goal.

Though a DMC is often a highly individual experience, we can relate this to L2 learning, as a DMC is an important phenomenon because teachers can play an important role in helping to transfer the energy of a DMC into a more conventional form (preface xi, pp. 135-136). We concluded further investigation was necessary as to how teachers regain motivation and hopefully toward directed motivational currents (DMC), which not only provide direction for action, but also energize action (Dörnyei et al., 2016).

\section{Survey on Demotivational Factors}

\section{Research Questions}

The main research questions addressed in this study are:

Part 1. What factors in a questionnaire are salient for teacher demotivation among language teachers in Japan?

Part 2. What is one factor that demotivated you most in your teaching career, and how did you get it over? Do you have any hobby, activity, or lessons you have been doing over many years? What are the factors that help you to continue it (them)? Do you think we can apply these tips for continuing to enhance students' learning?

\section{Method}

Participants. Thirty four participants completed this survey.

Table 1

Participants' Background Information

\begin{tabular}{|c|c|c|c|c|c|}
\hline & N (\%) & N (\%) & & & Total \\
\hline Gender & Male $9(26.5 \%)$ & Female 25 (73.5\%) & & & 34 \\
\hline Age & $\begin{array}{l}20 \text { ths } \\
1(2.9 \%)\end{array}$ & $\begin{array}{l}\text { 30ths } \\
3(8.8 \%)\end{array}$ & $\begin{array}{l}40 \text { ths } \\
11(32.3 \%)\end{array}$ & $\begin{array}{l}\text { Over } 50 \\
19(55.8 \%)\end{array}$ & $\begin{array}{l}34 \\
(100 \%)\end{array}$ \\
\hline First Language & $\begin{array}{l}\text { Japanese } \\
94 \%)\end{array}$ & $\begin{array}{l}\text { 1English/Chinese } \\
1 \text { English/Thai, } 1 \text { Eng }\end{array}$ & & & 34 \\
\hline Teaching subject & $\begin{array}{l}\text { (college)`English } 23 \\
(67.6 \%)\end{array}$ & $\begin{array}{l}\text { (college) Japanese } 6 \\
\text { French } 1\end{array}$ & $\begin{array}{l}\text { (college) } \\
\text { Science } 2\end{array}$ & $\begin{array}{l}\text { Sociology } 1 \\
\text { Geography } 1\end{array}$ & 34 \\
\hline Years of teaching & $\begin{array}{l}1-5 \text { years } \\
3(8.8 \%)\end{array}$ & $\begin{array}{l}6-10 \text { years } \\
3(8.8 \%)\end{array}$ & $\begin{array}{l}\text { More than } 11 \\
28(82.3 \%)\end{array}$ & & 34 \\
\hline Type of hiring & $\begin{array}{l}\text { Part time } \\
18(52.9 \%)\end{array}$ & Full-time (non- tenured) 3 (8.8\%) & $\begin{array}{l}\text { Full-time (tenured) } \\
13(38.2 \%)\end{array}$ & & \\
\hline
\end{tabular}


As for the years of teaching, 3 (8.8\%) have taught 1-5 years, 3 (8.8\%) 6-10 years, and 28 (82.3\%) have taught for more than 11 years. As for the type of hiring, 18 (52.9\%) were hired on a part-time basis, 3 (8.8\%) were hired on a full-time basis (non-tenured), and 13 (38.2\%) have a part-time teaching job while hired as a full-time faculty. 5 out of 23 part-time teachers were male teachers. Similarly 4 out of 13 full-time teachers were male. In other words, about $44 \%$ of male and $36 \%$ of female teachers are hired on a full-time tenured basis.

Materials. A questionnaire was developed which used a five-point Likert scale format adopted from the Teacher Job Satisfaction Questionnaire (TJSQ) by Hughes (2006). Items concerning student attitudes in class were derived from results from previous research, choosing the highest 18 highest factors.

Open-ended questions such as "What is one factor that demotivated you most in your teaching career, and how did you get it over? Do you have any hobby, activity, or lessons you have been doing over many years? What are the factors to continue it (them)? Do you think we can apply these tips for continuing to enhance students' learning?” were made and checked by three researchers.

Procedure and statistical analysis. Initially, the survey was written in Japanese. Then, it was translated into English (see Appendix for an English version of the survey). Since the first semester of Japanese school ends in July, researchers had to rely on e-mail access and the grapevine of colleagues. We collected the questionnaires from June 23rd to July 16th. Out of 37 questionnaires, 3 were not returned, and the total number was 34 in the end.

All Likert scales were scored from 5 (strongly demotivate) to 1 (least demotivate). We put 0 for each item that the participants skipped. After all the data were coded in a spreadsheet, data were calculated in terms of means because the researchers wanted to focus more on qualitative data. Descriptive statistics for all questions were generated and reported. At the bottom of the questionnaire, the participants were asked to write about other factors that may demotivate them, or their comments.

For the qualitative part, most of the participants answered all of the questions, but because of limited space, only salient and/or insightful responses are reported.

\section{Results and Discussion}

The survey revealed that in the first factor related to student attitudes, the items "forget to do homework," "use cell-phones in class," and "when students take a rebellious attitude" demotivate the teachers the most although the differences were not significant. Table 2 shows the mean differences of the students' behaviors in descending order.

Table 2

Students' Attitudes for Teacher Demotivation

\begin{tabular}{|c|c|c|c|c|}
\hline Students' attitudes & Sum & $M$ & Range & $\mathrm{n}=34$ \\
\hline Forget to do homework & 129.00 & 3.79 & 5.00 & \\
\hline Use cell-phones in class & 126.00 & 3.70 & 5.00 & \\
\hline Take a rebellious attitude & 125.00 & 3.67 & 4.00 & \\
\hline Are not interested in studying & 124.00 & 3.64 & 4.00 & \\
\hline Sleep & 119.00 & 3.50 & 5.00 & \\
\hline Talk to each other & 118.00 & 3.47 & 5.00 & \\
\hline Forget to bring textbooks/dictionaries & 115.00 & 3.38 & 5.00 & \\
\hline
\end{tabular}


Table 3 shows the results of the items related to class facilities, teaching materials and curriculum. The mean numbers were the largest for "No consistency in curriculum with clear goals," and "Classroom facilities including audio visual equipment are poor." Surprisingly, "Low teacher evaluation from students," was not a strong factor for demotivation.

Table 3

Class Facilities, Teaching Materials, and Curriculum for Teacher Demotivation

\begin{tabular}{|c|c|c|c|c|}
\hline & Sum & $M$ & Range & $\mathrm{n}=34$ \\
\hline No consistency in curriculum with clear goals & 121.00 & 3.56 & 5.00 & \\
\hline Classroom facilities/audio visual equipment are poor & 110.00 & 3.23 & 5.00 & \\
\hline Teaching method and textbooks are fixed & 106.00 & 3.11 & 5.00 & \\
\hline Low teacher evaluation from students & 103.00 & 3.02 & 5.00 & \\
\hline Large classroom size & 97.00 & 2.85 & 5.00 & \\
\hline Abilities differ greatly in one class & 85.00 & 2.50 & 4.00 & \\
\hline
\end{tabular}

Table 4

Working Conditions for Teacher Demotivation

\begin{tabular}{|c|c|c|c|c|}
\hline Working conditions & Sum & $M$ & Range & $\mathrm{n}=34$ \\
\hline Too much work not related to teaching & 122.00 & 3.58 & 5.00 & \\
\hline Employment system is unstable & 111.00 & 3.26 & 5.00 & \\
\hline Lacking research fund and time & 109.00 & 3.20 & 5.00 & \\
\hline (Poor) relationship with colleagues & 106.00 & 3.11 & 5.00 & \\
\hline Commuting problems & 82.00 & 2.41 & 5.00 & \\
\hline
\end{tabular}

Notes. The biggest mean difference comes from "Too much work not related to teaching ( $\mathrm{M}=3.58)$ ", and "commuting problems (M $=2.41)^{\prime \prime}$.

\section{Other Factors for Teacher Demotivation}

In the last question in Part I, we asked participating teachers to write their factors for demotivation.

Teachers' statements can be seen below.

- When the level of the students and the level of the assigned textbook has much discrepancy. When I don't have enough time to prepare for teaching.

- In a seminar class, I saw one student copying all the answers another student’s.

- When I have to tell students that they have too many absences.

- When my health condition fails.

- Low pay.

- (I am employed as a part-time teacher) When I find out that other teachers, especially full time teachers are not interested in education.

- When part-time teachers ask for improvements in teaching materials and curriculum but full-time teachers do not try to accommodate these.

- When the treatment of part-time teachers is not good as in "black enterprises" and are treated as "one-time-use" commodities.

- Deterioration of management (of the university)

- No response from students in class (2 people) 
- Supplemental teaching material that I spent so much time preparing is hardly used.

- I have to be cautious of how I am being seen by other colleagues.

- Class schedule is changed because of school events.

\section{Results Part 2}

Table 5

What Is One Factor That Demotivated You Most in Your Teaching Career? How Did You Get Over It?

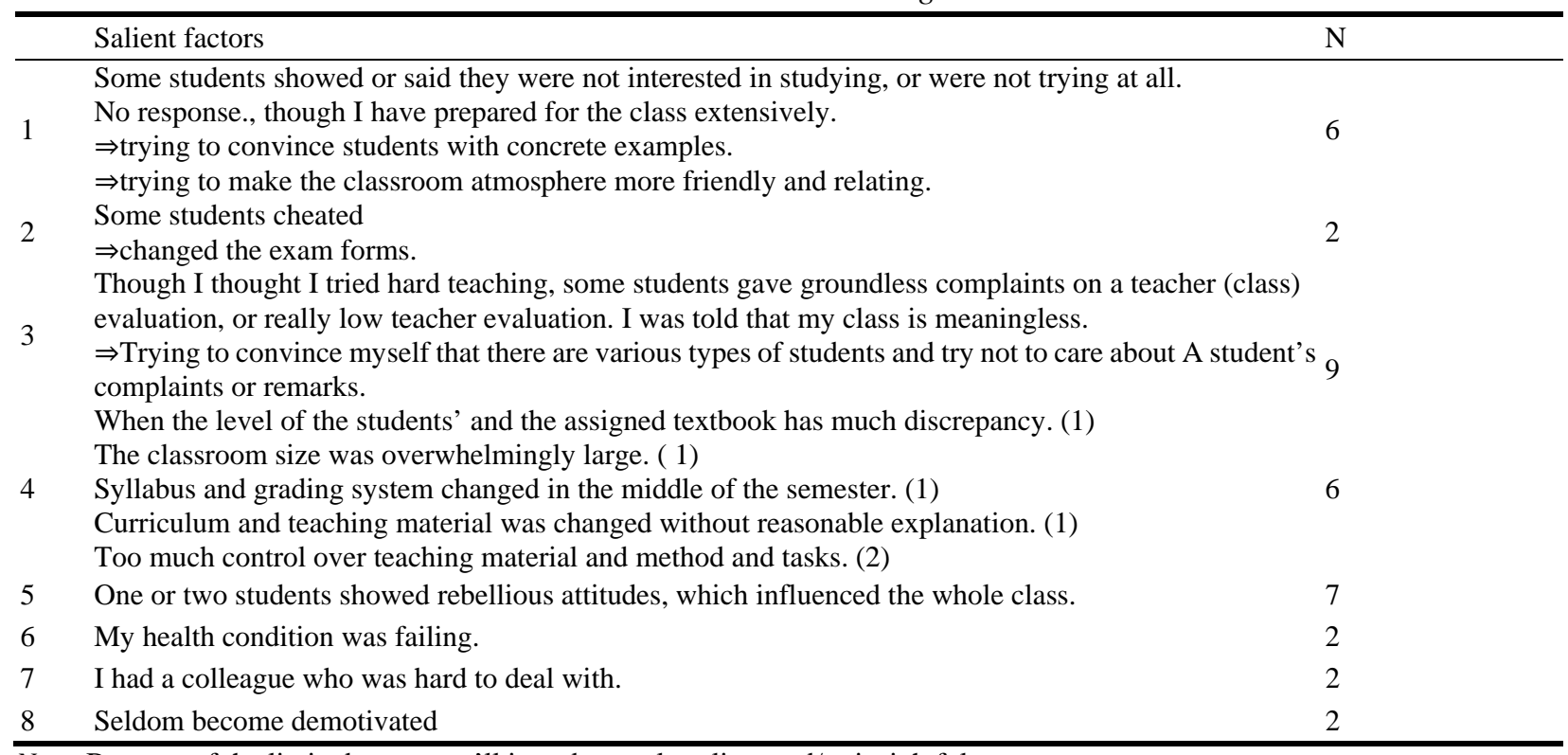

Note. Because of the limited space, we'll introduce only salient and/or insightful responses.

1. (over 50, Female, part-time)

None of the above factors in the questionnaire demotivate me because their attitudes are due to their own characteristics and problems on the teacher's side. The most demotivating factor lies in the educational institution because they don't try to change anything over many years despite incoming students being different.

$\Rightarrow \mathrm{I}$ have tried to think what I can do for the new types of students.

2. (40s, Female, part-time)

Until this year, it was up to each teacher to decide teaching materials and method. This year, however, at one university, everything is controlled-teaching material, method and tasks without much explanation from the teacher in charge, which requires much of our time to be spent on checking their writing. Also, though some classes have designated textbooks, the syllabus does not require using them. It is so hard to understand the intention of the new curriculum.

$\Rightarrow$ I was so demotivated at the beginning of the semester but since students tried hard to accomplish the assigned tasks, I tried to accommodate to students' needs and change or skip some of the tasks for the students to "enhance their abilities efficiently".

3. (over 50 years old, Female, ex-professor)

In a relatively large class, somehow this one female student showed a hostile attitude and in the teacher 
evaluation sheet, I had some attacking vicious remarks with extremely low ratings (I could identify her handwriting).

$\Rightarrow$ At that time, I wanted to quit my job but I tried to convince myself that it is only one student and maybe she had her own problems. Even though it was only one student, I had something to cause this hostility and sometimes (when I remember) it hurts me like a thorn.

4. (Over 50, Female, part-time)

I had to share a class with another teacher with a designated textbook, which was quite depressing.

$\Rightarrow$ I got over it after I stopped teaching the class.

5. (over 50, male, full-time)

One student wrote very good remarks on an exam but the same student criticized my class on a teacher evaluation sheet (they write their comments anonymously). I identified his handwriting.

6. (over 50, female, full-time tenured)

This student was using a cell-phone excessively in class. I told her to stop using it and she wrote on a teacher evaluation sheet that my attitude was threatening (mentioned my name, too). Her parents and the university accused me of power harassment and demanded my apology. I protested that the female student's attitude was not appropriate but the university said there was no such written code and gave me a strong warning not to pinpoint one student.

$\Rightarrow$ I quit my work because I just could not understand what or how to teach students anymore and since I didn't feel I had to apologize to the student and her parents for that and I gave up trying to defend myself, I just quit that university after consulting with my close colleague.

Table 6

Do You Have Any Hobbies, Activities, or Lessons You Have Been Doing Over Many Years?

Yes $=31($ No $=3$ out of 34$)$

Cooking, reading

Sports (gym, Japanese archery, Budo, soccer, walking, mountain climbing, swimming)

Reasons for Yes Research, participating in conferences and research groups

Japanese culture (poem, kimono school, shogi, tea-ceremony)

Art ( music appreciation, choir, drawing)

Volunteering (provide audio tapes to blind people), Child rearing, Secret

Table 7

What Are The Factors to Continue It (Them)?

Reasons for continuing these hobbies and/or activities

Enjoyable, fulfilling, challenging, relaxing, necessity and interest

Share them with company and friends

Practice for the same goal

Simply like doing it

To nurture myself and it can be beneficial for students, too.

Relieve stress

Intellectually stimulating, want something to do after retirement

(40s, female, full-time tenured) The teacher teaches us enjoyably, politely and willingly. She teaches us with appreciation that she can learn something through teaching us. Practicing with others toward the same goal, 
supporting them through enhancing their skills, and participating in competitions together is enjoyable. Also since there is an examination for proceeding to a higher grade, it is easy to set a goal and thus motivates me.

Table 8

Do You Think We Can Apply These Tips for Continuing to Enhance Students' Learning? Can You Give Us Concrete Examples?

\begin{tabular}{|c|c|}
\hline \multirow{11}{*}{$\begin{array}{l}\text { I don't think so. } \\
\text { I think so with key tips }\end{array}$} & Concrete examples (suggestions) $N=28$ (no answer 6) \\
\hline & $3 \quad$ I think so. 25 \\
\hline & Give a group task and evaluate as a team. \\
\hline & Making leaning interesting and fun. \\
\hline & Praising, continuing \\
\hline & Peer teaching \\
\hline & Noticing students' efforts \\
\hline & Trying to teach students how to be persistent \\
\hline & Trying to push students into learning situations without a way out \\
\hline & Teach students to be flexible \\
\hline & Try to form a good habit (that can be continued) \\
\hline
\end{tabular}

Teacher 1 (40s, female, literature)

I think we can apply them. Include things that get students interested. If teachers are successful making students feel interested, they want to learn willingly. For example, some students want to read children's literature in class and would like to talk about it or do a presentation. After all, if they are interested, they can continue.

Teacher 2 (40s, female, science)

If I am praised by other people, that enhances my motivation. I try to praise students who try to derive their answers from only tips, in a seminar type science class to come up with an answer. In the class, since there are about 100 students and it is extremely difficult to take care of every student, I recommend peer-teaching. Those who teach and who are taught tackle tasks seriously. Student-teachers are praised each time.

Teacher 3 (30s, male, English, part-time)

Therefore (since I've tried and spend a lot of time on my hobbies), when we have students who have not formed a study-habit yet, I try to guide them to form the habits with much time and effort.

Teacher 4 (40s, female, English, full-time)

Try to communicate well with students and try to observe them well. Praise students who are trying hard or maturing even for the things outside of class. Praise them, or feel happy for them. If students find it easy to talk to me, they will come and talk to me or ask for advice about learning English even when they are no longer in my class. In that case, I try to answer their questions sincerely.

Teacher 5 (50s, female, Japanese, full-time)

Sharing my experience with students that I am continuing my activities in this way, and tell them the covert efforts, might make students interested.

Teacher 6 (50s, female, Japanese, full-time)

To help students know learning is to continue. It's more important giving a chance to experience them than just telling them about it. Have them do homework as a routine work and if they forget to do homework, persistently remind them of doing it, and giving a sense of accomplishment, however little it may be. 
Teacher 7 (40s, female, Japanese, full-time)

The sense that you are just enjoying things is more likely instant and not persistent. But if students can experience interesting things with intellectual stimuli, they may want to move on. If we can offer teaching syllabi, methods that can stimulate students as "Oh, I understand this”, "this is interesting”, "I want to explore more”, "I want to continue”, then it will be related to more effective teaching.

\section{Conclusion With Limitations and Implications}

As for the research question part 1, i.e., "What factors in a questionnaire are salient for teacher demotivation among language teachers in Japan,” we would conclude from the participants' answers that "students' attitudes” influenced the teachers' demotivation more than the other two categories: "class facilities/teaching materials/and curriculum," and their "working conditions." From this result, it was revealed that the "students' attitudes" were the crucial factor to demotivate the teachers. When we carefully look at each item of that category, "students' attitudes," the students' "rebellious attitude” ranked the third among the seventh items relating to students' attitude, while the strongest demotivating factor was the students' "forget to do homework," followed by the students' "use cell-phones in class." Students doing the homework and not using cell-phones during class were appropriate behaviors, yet the reality is there were many Japanese students who could not do that. Teachers have been tacking these unwilling situations.

This research revealed that lacking fundamental attitudes and manners by the students has been a strong demotivating factor for teachers. As a matter of fact, this result is a little different from our previous expectations; since Japanese teachers have gotten so used to these unwelcoming situations of the students that they would take "rebellious attitude of a student” more seriously as a demotivating factor. It seems that the teachers sacrifice their personal, psychological salience of peacefulness for the sake of their professional acts.

Concerning the student's “taking a rebellious attitude,” some free-writings were on such student's rebellious attitudes and showed the process of how the teachers confronted, reacted, and overcame them in the past.

As for part 2 of our research question, i.e., "What is one factor that demotivated you most in your teaching career, and how did you get it over?” Nine teachers mentioned about receiving low teacher (class) evaluations from the students. We noticed that this was a little contrary to the result we have gotten from the Likert-scale questions. It was shown in Table 3, the mean of the "low teacher evaluation from students" was 3.02, which was fourth among six items of that category, "class facilities/teaching materials/and curriculum.” We assume from the discrepancy that the teachers were demotivated by the students' inconsiderate or low evaluation to their classes yet, they tried finding the answers to those students' assaults and convinced themselves that the "groundless" low evaluations were only from a single person or a small number of the students or it had nothing to do with their teaching but rather was a personal attack.

DMC is used as one of the main strategic frameworks to construct this research in order to grasp how teachers in Japan find solutions and lead themselves from not enjoyable psychological states into enjoyable ones. It was found that many of the participants had refreshing activities elsewhere in addition to their job of teaching. From the participants' comments, it was clear that there were various tips in order to conquer the negative demotivating circumstances and place themselves in DMC, which the teachers even agreed to apply to their main job of teaching. 
Since there has not been enough research on teacher demotivation to grasp the whole picture of it, there should be more research planned and conducted with teachers in Japan. As suggested in Ushioda (2013, p. 11), the current tide of international interest in L2 motivation is driven not only by the pursuit of new theoretical frameworks and conceptual analyses, in light of globalization and the global status of English. Current interest in L2 motivation is driven also by local practical concerns in an era where globalization, global English and concomitant critical issues have a significant impact on educational policy, language pedagogy and, of course, student motivation. It is hoped that this study will offer some insights to further research on motivation/demotivation, and will be beneficial for facilitating better SLA learning and teaching.

\section{References}

Apple, M., Da Silva, D., \& Fellner, T. (2013). Exploring classroom-based constructs of EFL motivation for Science and Engineering students in Japan. In T. Matthew, T. Apple, D. Da Silva and T. Fellner (Eds.), Language learning motivation in Japan (pp. 54-74). Bristol, U.K.: Multilingual Matters.

Arai, K. (2004). What “demotivates” language learners?: Qualitative study on demotivational factors and learners' reactions. Bulletin of Toyo Gakuen University, 12, 39-47.

Ayadin, S. (2012). Factors causing demotivation in EFL teaching process: A case study. The Qualitative Report, 17(101), 1-13.

Berwick, R., \& Ross, S. (1989). Motivation after matriculation. Are Japanese learners of English still alive after exam hell? JALT Journal, 11(2), 193-210.

Clark, B. (2010). Saving Japan’s universities. Japan Times, Tuesday, August 17, 2010.

Connie, R. J. (2000). Factors influencing motivation and de-motivation of Mexian EFL teachers (Paper presented at The Annual Meeting of Teachers of English to Speakers of Other Languages, Vancouver, BC, Canada).

Dörnyei, Z. (2001). Teaching and researching motivation. Harlow, U.K.: Pearson Education.

Dörnyei, Z., Henry, A., \& Muir, C. (2016). Motivational currents in language learning: Frameworks for focused interventions. New York, NY: Routledge.

Falout, J., \& Maruyama, M. (2004). A comparative study of proficiency and learner demotivation. The Language Teacher, 28(8), 3-9.

Kim, T. Y., \& Kim, Y. K. (June, 2015). Initial career motives and demotivation in teaching English as a foreign language: Cases of Korean EFL teachers. Porta Linguarum, 24, 77-92.

Kiziltepe, Z. (2008). Motivation and demotivation of university teachers. Teacher and Teaching, 14(5-6), 515-530.

Kozloski, W. (2002). Motivation to teach English: A study of EFL instructors in Japan (Unpublished paper presented at The 4th Temple University Japan Applied Linguistics Colloquium).

Oxford, R., \& Shearin, J. (1994). Language learning motivation: Expanding the theoretical framework. The Modern Language Journal, 78, 12-28.

Sakai, H., \& Kikuchi, H. (2009). An analysis of demotivation in the EFL classroom. System 37(1), 57-69.

Sakai, H., \& Koike, H. (2008). Changes in Japanese university students' motivation to learn English: Effects of volunteering in an International event. JALT Journal, 30(1), 51-67.

Sugino, T. (2010). Teacher demotivational factors in the Japanese language teaching context. PROCEDIA, 2(7), total 7 pages.

Tsuchiya, M. (2006). Factors in demotivation of lower proficiency English learners at college. The Kyushu Academic Society of English Language Education (KASELE), 34, 87-96.

Ushioda, E. (2013). Foreign language motivation research in Japan: An “insider” perspective from outside Japan. In T. Matthew, T. Apple, D. Da Silva and T. Fellner (Eds.), Language learning motivation in Japan (pp. 1-14). Bristol, U.K.: Multilingual Matters.

Williams, M., \& Burden, R. (1997). Psychology of language teachers. Cambridge, U.K.: Cambridge University Press.

Yan, H. (2009). Student and teacher de-motivation in SLA. Asian Social Science, 1(4), 109-112. 


\section{Appendix}

Teacher Demotivation Questionnaire

Directions: The following statements refer to factors that may influence the way a teacher feels about his/her job. These factors are related to teaching and to the individual's perception that may demotivate him/her. When answering statements, circle the numeral which represents the degree indicated as below.

Key: 5 (Strongly demotivate), 4 ( Pretty much demotivate) 3(Neutral), 2 (No so much), 1( Least demotivate)

Circle the background information

1. Gender (1. male 2. female )

2. Age (1. 20s 2. 30s 3. 40s 4. 50s up)

3 . Your first language (1. Japanese 2. Other

4 . Institution (1. University 2. Other ) subject

5 . Years of teaching (1. 1-5 yrs 2. 6-10 yrs 3. more than 11 years)

6 . Type of hiring (1. part-time basis 2. full-time basis (non- tenured) 3. full-time basis (tenured))

When in class, students

Talk to each other 54321

Use cell-phones 54321

Forget to do homework. 54321

Forget to bring textbooks/dictionaries 54321

Sleep 54321

Are not interested in studying 54321

Are not interested in foreign languages 54321

Take a rebellious attitude 54321

Low teacher evaluation from students 54321

Abilities differ greatly in one class 54321

Large Class size 54321

Classroom facilities including audio visual aids are poor. 54321

Teaching material and method are fixed. 54321

No consistency in curriculum with clear goals 54321

Commuting problems 54321

Employment system is unstable 54321

Lacking research time and fund 54321

Too much for not related to teaching 54321

(Poor ) relationship with colleagues 54321 